\title{
DDX39B Gene
}

National Cancer Institute

\section{Source}

National Cancer Institute. DDX39B Gene. NCI Thesaurus. Code C118922.

This gene plays a role in both RNA splicing and mRNA transport. 